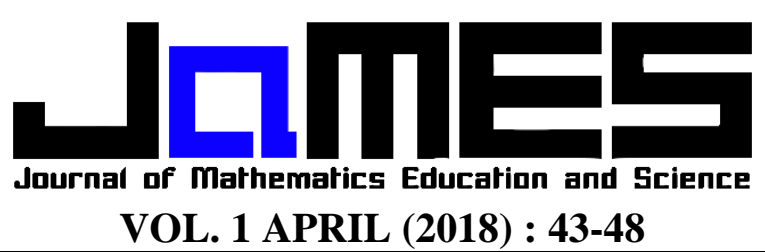

p-ISSN: 2621-1203

e-ISSN: 2621-1211

\title{
CARA BERPIKIR SISWA SEKOLAH DASAR DALAM MENYELESAIKAN SOAL OPERASI PERKALIAN
}

\author{
Nurul Ilmiyah ${ }^{1}$ \\ Universitas Nahdlatul Ulama Sunan Giri, nurulilmiyah@unugiri.ac.id ${ }^{1}$ \\ Received : 20 Maret 2018, Accepted : 1 April 2018, @ Mathematics Education Unugiri 2018
}

\begin{abstract}
Multiplication is one of the important materials taught in elementary school because it is very often found its application in everyday life. In addition, mathematical topics for higher levels still use multiplication operations. In essence the plot is a recurrent sum, but not necessarily the multiplication concept is taught in a way that depends only on repeated summations. Students need to be trained to shift from thinking adding (additive thinking) to multiplicative thinking. Multiplicative Thinking is a prerequisite for being able to solve problems involving fractions, decimal numbers, percent numbers, and comparisons. The purpose of writing this article is to identify and describe the way of thinking elementary school students, especially students in grade 3 and 4 in solving multiplication counting problems. The classification of students into the form of multiplicative or additive ways of thinking seen from the work of students then grouped based on its characteristics.
\end{abstract}

Keywords: multiplication, multiplicative thinking, additive thingking

\begin{abstract}
Abstrak
Perkalian merupakan salah satu materi penting yang diajarkan pada jenjang sekolah dasar karena amat sering dijumpai penerapannya dalam kehidupan sehari-hari. Selain itu, topik-topik matematika untuk jenjang ynag lebih tinggi masih menggunakan operasi perkalian. Pada dasarnya perklaian merupakan penjumlahan yang berulang, namun tidak seharusnya konsep perkalian diajarkan dengan cara hanya bergantung pada penjumlahan berulang semata. Siswa perlu dilatih untuk bergeser dari berpikir penjumlahan (additive thinking) ke berpikir perkalian (multiplicative thinking). Multiplicative Thinking adalah prasyarat untuk untuk dapat menyelesaikan permasalahann yang melibatkan pecahan, bilangan desimal, bilangan persen, dan perbandingan. Tujuan penulisan artikel ini adalah mengidentifikasi dan mendeskripsikan cara berpikir siswa sekolah dasar terutama siswa kelas 3 dan 4 dalam menyelesaikan soal operasi hitung perkalian. Adapun pengklasifikasian siswa ke dalam bentuk cara berpikir multiplicative atau additive dilihat dari hasil pekerjaan siswa kemudian dikelompokkan berdasarkan ciri-cirinya.
\end{abstract}

Kata kunci: perkalian, multiplicative thinking, additive thingking

\section{Pendahuluan}

Kebanyakan siswa menunjukkan antusiasme dan ketertarikan yang tinggi dalam pembelajaran matematika ketika memasuki sekolah dasar. Parmjit [1] menjelaskan bahwa lebih dari $3 / 4$ siswa pada kelas 1 hingga 3 sekolah dasar menunjukkan kesukaannya terhadap matematika. Namun oada kenyataannya, ketika siswa berada pada jenjang pendidikan yang lebih tinggi, mereka justru menunjukkan ketidaksukaannya terhadap matematika karena mereka menganggap matematika adalah pelajaran yang sulit dan membosankan.

Melihat kenyataaan diatas, jika pembelajaran matematika dikelas dirancang untuk pembelajaran yang menyenangkan dan bermakna mulai dari jenjang sekolah dasar, hal ini dapat memelihara antusiasme siswa terhadap matematika sampai pada jenjang yang lebih tinggi. Oleh karena itu, penanaman rasa senang terhadap matematika perlu ditanamkan 
mulai jenjang sekolah dasar. Akan tetapi jika pembelajaran matematika dirancang hanya untuk mendengarkan dan menghafal, maka siswa akan kehilangan ketertarikan terhadap matematika bahkan sampai siswa memasuki jenjang yang lebih tinggi. Dengan demikian, pembelajaran pada jenjang ini harusnya melibatkan keaktifan siswa baik secara mental, fisik, maupun sosial.

Melihat pentingnya matematika, maka mata pelajaran matematika diberikan kepada siswa untuk membekali kemampuan berpikir logis, analitis, sistematis, kritis, dan kreatif, serta kemampuan bekerja sama. Depdiknas (dalam Shadiq, [2]) menyatakan bahwa matematika dan penalaran merupakan dua hal yang saling terkait, dalam memahami matematika memerlukan penalaran, dan sebaliknya kemampuan penalaran matematika dapat dipahami dan dipelajari dalam belajar matematika.

NCTM [3] menyatakan bahwa penalaran matematika dapat dicirikan sebagai salah satu bagian dari proses berpikir matematis. Solso, dkk [4] menjelaskan bahwa berpikir adalah suatu proses internal atau hanya ada sebagai tingkah laku yang dapat diukur. Lebih jauh Solso, dkk [4] mengatakan berpikir adalah suatu proses untuk melukiskan mental baru yang dibentuk melalui transformasi informasi berkaitan dengan interaksi atribut-atribut mental yang kompleks antara lain meliputi: interpretasi, pengkodean, keputusan, abstraksi, penalaran, pembayangan, dan pemecahan masalah. Teori piaget (dalam Rochmad [5]) menyatakan bahwa siswa memperoleh konsep-konsep dengan mengkonstruksinya dalam benak. Melalui pengamatan oleh indera, informasi masuk ke benak siswa.

Setiap siswa menggunakan cara (pola) berpikirnya masing-masing untuk menyelesaikan soal matematika termasuk soal yang melibatkan operasi hitung perkalian. Perkalian merupakan topik yang amat penting dalam pembelajaran matematika karena amat sering dijumpai penerapannya dalam kehidupan sehari-hari, selain itu topik-topik matematika untuk jenjang yang lebih tinggi masih menggunakan operasi perkalian. Tim PPPPTK matematika [6] menjelaskan bahwa perkalian adalah penjumlahan berulang dari bilangan-bilangan yang sama pada setiap sukunya.

Pendapat berbeda dikemukakan oleh Jacob [7] yang mengatakan bahwa "multiplication is more than repeated addition however, and its more complicated", artinya perkalian lebih dari sekedar penjumlahan yang berulang. Hal ini dipertegas oleh pernyataan Fisbein, Deri, Nello \& Marino (dalam Parmjit [1]), yang mengatakan bahwa penjumlahan berulang adalah model yang sederhana dari perkalian. Berdasarkan pendapat di atas, terlihat bahwa pada dasarnya perkalian merupakan penjumlahan yang berulang, namun tidak seharusnya konsep perkalian diajarkan dengan cara hanya bergantung pada penjumlahan berulang semata. Siswa perlu dilatih untuk bergeser dari berpikir penjumlahan (additive thinking) ke berpikir perkalian (multiplicative thinking).

Siemon, Breed dan Virgona [8] mengemukakan bahwa Multiplicative Thinking adalah prasyarat untuk dapat menyelesaikan permasalahan yang melibatkan pecahan, bilangan desimal, bilangan persen, dan perbandingan. Karena pengetahuan matematika kebanyakan biasanya mensyaratkan pemahaman terhadap bilangan rasional dan perbandingan (proportional reasoning) yang meliputi pecahan, bilangan desimal, dan rasio. Siswa tidak dapat memahami dan menggunakan konsep bilangan rasional jika pemahaman siswa tentang perkalian (dan pembagian) hanya terbatas pada bilangan cacah yang kecil (small whole number). Selain itu, Jacob [9] juga menjelaskan bahwa terdapat beberapa keuntungan jika siswa menggunakan pola pikir perkalian, diantaranya adalah keefektifan perhitungan dalam menentukan hasil suatu perkalian, selain itu dengan menggunakan pola pikir perkalian (multiplicative thinking), siswa dapat memahami sifat komutatif pada perkalian (commutativity) dan kebalikan dari 
operasi perkalian (inverse relations) yaitu pembagian. Misalnya, $6 \times 4=24$ sehingga 12 $\times 4=48.72: 8=9$, sehingga $9 \times 8=72.3 \times 7$ $=21$, sehingga $42: 7=6$.

Multiplicative thinking dikembangkan dari additive thinking. Steffe (dalam Parmjit, [1]) menjelaskan bahwa munculnya konsep perkalian didasarkan ketika anak mengkonstruk gabungan dari kesatuankesatuan (units). Mulligan, Mitchelmore, dan Watson (dalam Jacob, [7]) menyimpulkan bahwa situasi perkalian atau permasalahan yang melibatkan perkalian meliputi tiga aspek, yaitu (i) kelompok-kelompok dari sesuatu yang mempunyai jumlah anggota yang sama (groups of equal sizel a multiplicand), (ii) banyaknya kelompok-kelompok tersebut (numbers of groups/ the multiplier), dan (iii) hasil kali (the total amount/ the product).

Berdasarkan pernyataan di atas, maka peneliti tertarik untuk melakukan penelitian dengan judul "Pola Pikir Siswa Sekolah Dasar Dalam Menyelesaikan Soal Operasi Hitung Perkalian".

Dengan tujuan yaitu mengidentifikasi dan mendeskripsikan pola pikir siswa sekolah dasar terutama siswa kelas 3 dan 4 dalam menyelesaikan soal operasi hitung perkalian.

Adapun manfaat dari penulisan artikel ini adalah sebagai informasi bagi guru sekolah dasar tentang cara pikir siswa dalam menyelesaikan soal operasi hitung perkalian ditinjau dari cara pikir perkalian (Multiplicative Thinking) atau cara pikir penjumlahan (Additive Thinking).

\section{Pembahasan}

Solso, dkk [4] menyatakan bahwa berpikir adalah proses yang membentuk representasi mental baru melalui transformasi informasi oleh interaksi kompleks dari atribusi mental yang mencakup pertimbangan, pengabstrakan, penalaran, penggambaran, pemecahan masalah logis, pembentukan konsep, kreativitas, dan kecerdasan. Sedangkan Siegler (dalam Santrock [10]) berpendapat bahwa berpikir adalah pemrosesan informasi. Hal ini dipertegas oleh pernyataan
Winkel [11] yang menyatakan bahwa berpikir digambarkan sebagai suatu rangkaian kejadian atau peristiwa dalam otak yang meliputi urutan langkah pengolahan informasi, dari saat diterima sampai saat dilepas lagi. Maksud dari pemrosesan informasi adalah bagaimana siswa mengolah informasi, memonitornya, dan menyusun strategi yang berkenaan dengan informasi tersebut. Informasi tersebut disimpan dan diproses oleh otak kemudian ditampilkan dalam perilaku yang dapat diamati.

Lebih dalam, Solso, dkk [4] membagi ide dasar tentang berpikir, yaitu (1) berpikir adalah kognitif terjadi secara internal dalam pemikiran tetapi keputusan diambil lewat perilaku, (2) berpikir adalah proses yang melibatkan beberapa pengetahuan dalam sistem kognitif, (3) berpikir bersifat langsung dan menghasilkan perilaku yang memecahkan masalah atau langsung menuju solusi.

Berdasarkan pendapat para ahli, dapat disimpulkan berpikir adalah suatu bentuk pemrosesan informasi yang terjadi dalam diri seseorang yang meliputi pengelolaan informasi, penyimpanan informasi, dan pemanggilan kembali informasi dalam memori.

Steffe (dalam Parmjit, [1]) mengatakan bahwa the emergence of a concept of multiplication is possible once a child has constructed composite units, that is units are themselves composed of units. Artinya, munculnya konsep perkalian dimungkinkan ketika seorang anak mengkonstrukgabungan dari kesatuan-kesatuan (units). Mulligan, Mitchelmore, dan Watson (dalm Jacob, [7]) menyimpulkan that led to the conclusion that children must first come to recognise multiplicative situations as involving three aspects: group of equal size (a multiplicand), number of groups (multiplier), and a total amount (the product). Artinya, anak-anak harus mengenali situasi perkalian yang melibatkan tiga aspek, yaitu (i) kelompokkelompok dari sesuatu yang mempunyai jumlah anggota yang sama (pengali), (ii) banyaknya kelompok-kelompok tersebut (yang dikali), dan (iii) hasil kali (product). 
Lebih jauh, Clark dan Kamii, Boulet dan Lamon (dalam Jacob, [9]) menjelaskan bahwa

in particular, led to the conclusion that it was identification or construction of the multiplicand and the multiplier within a situation, and the simultaneous coordination of these factors, that signified a multiplicative to a situation.

Artinya, mengidentifikasi yang dikali (multiplicand) dan pengali (multiplier) kedalam suatu situasi dan bersama dengan faktor-faktornya, maka itu menandakan situasi dari sebuahperkalian.

Jadi, perkalian mengandung tiga aspek, yaitu groups of equal size (multiplicandl yang dikali), numbers of group (multiplier/ pengali), dan total (hasil kali).

Tabel 1 Keterkaitan equal group, numbers of group dan total

\begin{tabular}{|c|c|}
\hline $\begin{array}{l}\text { Equal group } \\
\text { Menghitung keseluruhan }\end{array}$ & $\begin{array}{l}\text { Melihat equal group } \\
\text { sebagai sebuah gabungan } \\
\text { dari kesatuan (unit) }\end{array}$ \\
\hline $\begin{array}{l}\text { Numbers of group } \\
\text { Melihat bentuk dari } \\
\text { setiap grup, menghitung } \\
\text { semulur grup } \\
\text { Contoh: } 1 \text { grup, } 2 \text { grup, } 3 \\
\text { grup, ... }\end{array}$ & $\begin{array}{l}\text { Menguraikan bnayaknya } \\
\text { grup kedalam bagian- } \\
\text { bagian dari keseluruhan } \\
\text { yang mudah dipahami. } \\
\text { Contoh: } 6 \text { grup dapat } \\
\text { diuraikan menjadi } 3 \text { grup } \\
\text { dan } 3 \text { grup atau } 5 \text { grup } \\
\text { dan } 1 \text { grup }\end{array}$ \\
\hline $\begin{array}{l}\text { Total } \\
\text { Menghitung keseluruhan, } \\
\text { meloncati perhitungan }\end{array}$ & $\begin{array}{l}\text { Jumlah dilihat sebagai } \\
\text { gabungan dari gabungan- } \\
\text { gabungan. } \\
\text { Contoh: } 18 \text { adalah } 2 \times 9 \text {, } \\
9 \times 2,6 \times 3,3 \times 6\end{array}$ \\
\hline
\end{tabular}

Beberapa contoh yang dapat digunakan untuk memperlihatkan equal group adalah banyaknya roda pada 3 buah mobil, banyaknya jari yang dimilki oleh 3 orang, banyaknya kaki dari 4 ekor kambing.

Siemon [12] menjelaskan bahwa Multiplicative Thinking is characterised by:

(1) Capacity to work flexibly and efficiently with an extended range of numbers (for examples, larger whole numbers, decimals, common fractions, ratio, and percent)
(2) An ability to recognise and solve a range of problems involving multiplication and/ or division including direct and indirect proportion; and

(3) The means to communicate this effectively in a variety of ways (for examples, words, diagrams, symbolic expressions, and written algorithms).

Artinya, berpikir Multiplicative dikenali dengan:

(1) Kemampuan untuk bekerja secara fleksibel dan efisien dengan sebuah bilangan yang rentangnya diperluas (contoh, bilangan cacah yang besar, bilangan desimal, pecahan biasa, perbandingan, dan persen).

(2) Kemampuan untuk mengenali dan menyelesaikan masalah yang melibatkan perkalian dan/ atau pembagian meliputi pembagian langsung dan taklangsung, dan

(3) Alat untuk mengkomunikasikan keefektifan ini pada cara yang bermacammacam (contoh, kata, diagram, ungkapan simbol, dan menulis algoritma).

Siemon [12] juga menjelaskan In short, multiplicative thinking is indicated by capacity to work flexibly with the concepts, representations, and strategies of multiplication (and division) as they accur in a wide range of contexts. Artinya, Multiplicative Thinking adalah kemampuan untuk bekerja secara fleksibel dengan konsep, representasi, dan strategi dari perkalian (dan pembagian) yang terjadi pada konteks yang lebih luas.

Penjumlahan digunakan untuk menggabungkan suatu nilai. Sebagai contoh, jika Ibu mempunyai 3 buah apel kemudian Ayah memberi Ibu 6 buah apel, maka total apel yang dimiliki ibu adalah 9 buah apel. Inilah yang disebut cara pikir Additive. Additive thinking is present when a constant number is added to a value to get the resulting value. Maksudnya adalah cara pikir Additive ditunjukkan ketika sebuah bilangan konstan ditambahkan dengan sebuah nilai untuk mendapatkan hasil nilai. 
Multiplication is the addition of equal groups. Artinya, perkalian adalah penjumlahan dari grup yang sama. Misalnya, Ibu memiliki 3 buah keranjang yang masing-masing berisi 6 buah apel, maka jumlah apel yang dimiliki Ibu adalah 18 buah apel. Jadi, $3 \times 6$ sama dengan 18. Inilah yang dimaksud cara pikir Multiplicative. Multiplicative thinking is present when a value is multiplied by a constant rate to get the resulting value. Artinya, cara pikir multiplicative ditunjukkan ketika sebuah nilai dikalikan dengan angka konstan untuk mendapatkan hasil nilai.

Tabel 2 Perbedaan Cara Pikir Additive dan Cara Pikir Multiplicative

\begin{tabular}{|c|c|c|c|c|c|}
\hline \multicolumn{3}{|c|}{ Additive Thinking } & \multicolumn{3}{|c|}{ Multiplicative Thinking } \\
\hline 。 & +3 & 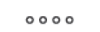 & ○ & $\times 3$ & 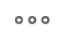 \\
\hline$\circ \circ$ & +3 & 00000 & $\circ \circ$ & $\times 3$ & $\begin{array}{l}\circ \circ \\
\circ \circ \\
\circ \circ\end{array}$ \\
\hline$\circ \circ \circ$ & +3 & ०००००० & $\circ \circ \circ$ & $\times 3$ & $\begin{array}{l}\circ \circ \circ \\
\circ \circ \circ \\
\circ \circ \circ\end{array}$ \\
\hline 0000 & +3 & ००००००० & 0000 & $\times 3$ & $\begin{array}{l}0000 \\
0000 \\
0000 \\
0000\end{array}$ \\
\hline
\end{tabular}

Berikut ini contoh dari hasil pekerjaan siswa dengan menggunakan cara pikir "Multiplicative" dan cara pikir "Additive". "A muffin recipe requires $2 / 3$ of cup of milk. Each recipe makes 12 mussins. How many muffins can be made using 6 cups of milk"

Artinya, sebuah resep kue membutuhkan 2/3 cangkir susu. Setiap resep menghasilkan 12 kue. Berapa banyak kue yang dapat dihasilkan jika menggunakan 6 cangkir susu?

Di bawah ini adalah hasil pekerjaan siswa yang menggunakan cara pikir Additive.

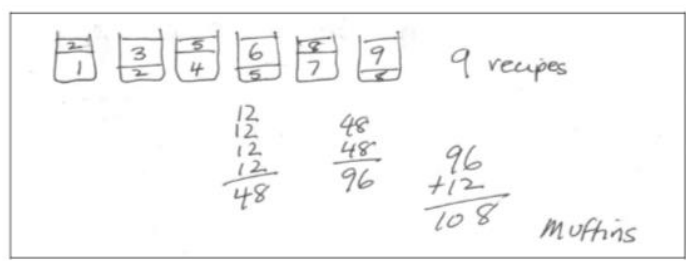

Berdasarkan hasil pekerjaan siswa di atas, maka cara penyelesaian yang dilakukan siswa digolongkan kedalam cara pikir Additive. Cara yang dilakukan siswa adalah menjumlahkan 2/3 berulang-ulang untuk menentukan banyaknya resep yang digunakan sampai akhirnya mendapatkan 6 cangkir susu. Ternyata siswa menjumlahkan $2 / 3$ sebanyak 9 kali, maka penggunaan 6 cangkir susu tersebut melibatkan 9 resep. Karena 1 resep mengasilkan 12 kue, maka siswa menjumlahkan 12 sebanyak 9 kali.

Di bawah ini adalah hasil pekerjaan siswa yang menggunakan cara pikir Multiplicative.

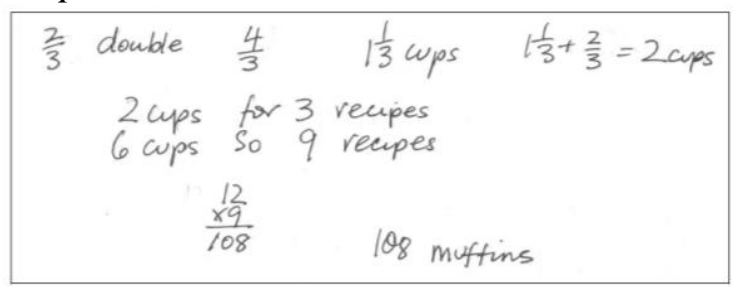

Berdasarkan hasil pekerjaan siswa di atas, maka cara penyelesaian yang dilakukan siswa digolongkan kedalam cara pikir Multiplicative. Siswa mengalikan $2 / 3$ dengan 3 dengan cara mengandakan $2 / 3$ kemudian menambahkan dengan $2 / 3$ sehinggan didapatkan 2 cangkir susu. Siswa berpikir jika 3 resep membutuhkan 2 cangkir susu, maka 9 resep membutuhkan 6 cangkir susu. Selanjutnya siswa mengalikan 12 dengan 9.

Contoh lain dari perbedaan cara pikir Additive dan cara pikir Multiplicative ditunjukkan oleh hasil penelitian Jacob [8]. Penelitin ini dilakukan terhadap 2 orang siswa kelas 3 dan 4 sekolah dasar di Australia. Didepan siswa diberikan 12 balok dengan ukuran yang sama dan siswa tidak diperbolehkan memegang balok-balok tersebut. Pertanyaan yang dilontarkan kepada siswa adalah "how many piles of three block they could get from twelvw blocks?" dan "how many blocks are in four piles of three blocks?"

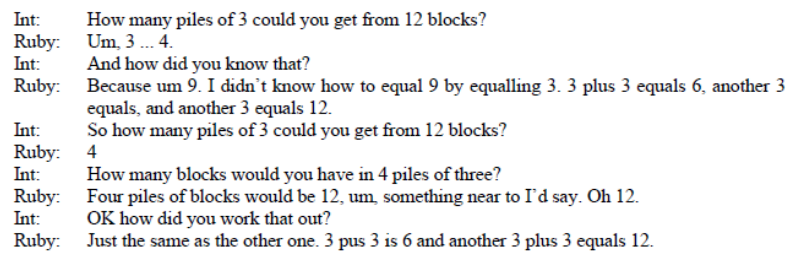

Berdasarkan hasil wawancara dengan siswa 1 (Ruby) dapat disimpulkan bahwa Ruby menggunakan cara pikir Additive untuk 
menyelesaikan pertanyaan yang diberikan. Terlihat bahwa, Ruby menggunakan double of group $(3+3=6,6+6=12)$ untuk menentukan banyaknya tumpukan dari 3 buah balok jika terdapat 12 balok. Selanjutnya Ruby juga melakukan cara yang sama untuk menentukan banyaknya jumlah balok dari 4 tumpukan tiga buah balok. Jadi, permasalahan yang melibatkan enjumlahan diselesaikan Ruby dengan cara pembagian.

Cara pikir yang berbeda ditunjukkan oleh siswa 2 (Nathan) sebagai berikut.

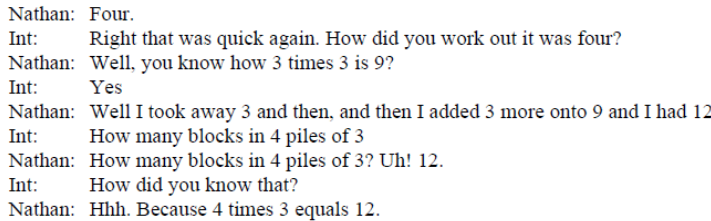

Nathan menggunakan cara pikir Multiplicative. Nathan menggunakan cara triple of group and 1 more group $(3 \times 3=9,9$ $+3=12$ ) untuk menentukan banyaknya tumpukan dari 3 buah balok jika terdapat 12 balok. Selanjutnya dalam menjawab berapa banyak jumlah balok dari 4 tumpukan tiga buah balok, Nathan menjawab $4 \times 3=12$. Dengan demikian, Nathan mengenali bahwa 4 adalah multiplier (pengali), 3 adalah multiplicand (yang dikali) dan 12 adalah hasil kali. Nathan tidak hanya menggunakan konsep perkalian dalam menyelesaikan soal yang melibatkan perkalian, tetapi juga memahami bagaimana perkalian dapat digunakan untuk menyelesaikan soal yang melibatkan pembagian.

\section{Penutup}

Pengklasifikasian pola pikir siswa didasarkan pada jawaban siswa yang disesuaikan dengan ciri-ciri berikut ini:

Tabel 3. Pengklasifikasian Pola Pikir Additive dan Multiplicative

\begin{tabular}{|c|c|}
\hline Additive Thinking & ative Thinking \\
\hline \begin{tabular}{|l}
$\checkmark$ \\
Menghitung \\
objek satu per \\
satu (counting \\
individual \\
objects)
\end{tabular} & $\begin{array}{ll}\checkmark & \text { Menghitung objek sebagai } \\
\text { kumpulan-kumpulan objek } \\
\text { (counting group of objects). } \\
\checkmark \quad \text { Mengenali bilangan sebagai } \\
\text { multiplier (pengali) dan } \\
\text { multiplicand (yang dikali). }\end{array}$ \\
\hline
\end{tabular}

\section{Referensi}

[1] Parmjit. Evolvement of Multiplicative Thinking in Children's Learning. Mara University of Technology, Malaysia (2004).

[2] Shadiq, Fajar. Pemecahan Masalah, Penalaran, dan Komunikasi. Disampaikan pada diklat Instruktur/ Pengembang Matematika SMA jenjang Dasar. Yogyakarta: Pusat Pengembangan Penataran Guru (PPPG) Matematika (2004).

[3] NCTM. Principles and Standards for School Mathematics. USA: Key Curriculum Press (2000).

[4] Solso, R. L. Psikologi Kognitif. Edisi Kedelapan. Boston: Allyn dan Baccon (2008).

[5] Rochmad. Pengembangan Model Pembelajaran Matematika beracuan Konstruktivisme yang Melibatkan Penggunaan Pola Pikir Induktif-Deduktif (Model PMBK-ID) untuk siswa SMP/ MTs. Disertasi. Surabaya: Unesa (2009).

[6] Tim PPPPTK. Pembelajaran Operasi Hitung Perkalian dan Pembagian Bilangan Cacah di SD. Yogyakarta: Pusat Pengembangan dan Pemberdayaan Pendidik dan Tenaga Kependidikan Matematika (2009).

[7] Jacob, Lorraine \& Willis, Sue. Recognising the Difference Between Additive Thinking and Multiplicative Thinking in Young Children. Proceedings of the 24th Conference of the Mathematics Education Research Group of australia. Sydney: Mathematics Education Research Group of Australia (2001).

[8] Siemon, Dianne., Breed, Margarita \& Virgona, Jo. -. From Additive to Multiplicative Thinking - The Big Challege of the Middle Years. RMIT University. School of Education.

[9] Jacob, Lorraine \& willis, Sue. - . The Development of Multiplicative Thinking in Young Children. Sydney: Mathematics Education Research Group of Australia.

[10] Santrock, John W. Psikologi Pendidikan. Jakarta: Kencana (2010).

[11] Winkel, W. S. Psikologi Pengajaran. Yogyakarta: Media Abadi (2004).

[12] Siemon, Dianne. Multiplicative thinking. RMIT University: A keynote address, Presented to the Mornington MAV Regional In-Service Conference (2008). 